\title{
Factors Influencing The Nurse Working Fatigue at The Inpatient Unit Idaman Regional Hospital Banjarbaru
}

\author{
Yunita Suwarni *, Izaak Zoelkarnain Akbar ${ }^{* *}$, Eko Suhartono ${ }^{* * *}$, Husaini ${ }^{*}$, Fauzie Rahman **** \\ * Master of Public Health, Faculty of Medicine, Lambung Mangkurat University, Indonesia \\ ${ }^{* *}$ dr. HM Ansari Saleh Regional General Hospital, South Kalimantan, Indonesia \\ **** Department of Biomechemistry, Faculty of Medicine, Lambung Mangkurat University, Indonesia \\ ***** Public Health Study Program, Faculty of Medicine, Lambung Mangkurat University, Indonesia \\ DOI: $10.29322 /$ IJSRP.10.08.2020.p104127 \\ http://dx.doi.org/10.29322/IJSRP.10.08.2020.p104127
}

\begin{abstract}
Bed Occupancy Rate (BOR) is a number that indicates the percentage of the level of use of the bed at a certain time unit in inpatient units. The high achievement of BOR shows that there is an increase in service usage. This condition also shows that the work activities of health workers in the room have also increased. Increased work activities can be the cause of nurses' work fatigue. Fatigue caused by several factors, among others shifts work, individual factors (health or illness, gender, age, education, workload, tenure, marital status and nutritional status). The research aims to analiyze factors influencing working fatigue in nurses at the inpatient unit Idaman Regional Hospital Banjarbaru. This research was an observational analytic study using a crosssectional design with a sample of 56. The research instrument used a questionnaire and the reaction timer application. Dependent variables were work fatigue and the independent variables were age, sex, work shift, work period, marital status and nutritional status. The test used is the Chi-Square test and the Logistic Regression test for multivariate analysis. The results showed that most work fatigues was the tired category by $75 \%$. There was no significant influence between work fatigue and age $(\mathrm{p}=0.633)$, $\operatorname{sex}(\mathrm{p}=0.642)$, work shift $(\mathrm{p}=0.741)$ and nutritional status $(\mathrm{p}=$ $0.484)$. There was a significant influence between work fatigue and work period ( $\mathrm{p}=0.046$, Exp $\mathrm{B}=5.294)$ and marital status ( $\mathrm{p}$ $=0.003$, Exp $\mathrm{B}=13.927)$. The most influential factor on work fatigue is marital status $(p=0.003, O R=13.927)$. There is an influence between the working period and marital status on work fatigue. There is no influence between age, gender, work shift and nutritional status. The most dominant factor influencing work fatigue is marital status.
\end{abstract}

Index Terms- work fatigue, age, sex, work shift, work period, marital status and nutritional status

\section{INTRODUCTION}

$\mathrm{T}$ The Idaman Banjarbaru Regional Hospital (RSD) is a stateowned hospital. Idaman Banjarbaru Hospital has complete facilities and services, including hemodialysis installation, VIP clinic polyclinic, Medical Checkup, PICU (Pediatric Intensive Care Unit), NICU (Neonatal Intensive Care Unit), Lapat Anak (Born to Get Child Deed) facilities and the availability of Children Deed a complete specialist doctor. Thus the Banjarbaru Idaman Hospital is used as a referral hospital for other hospitals that still have limitations in health care facilities in the Banjarbaru City area and outside Banjarbaru City (Profile of Idaman Hospital, 2019).

Bed Occupancy Rate (BOR) is a number that shows the percentage of bed use at a specific time in the inpatient unit. The standard ideal value of BOR $70-85 \%$ (Sudra, 2010). The 2019 data stated that BOR achievements in 8 inpatient rooms at the Idaman Banjarbaru Hospital were respectively as follows: BOR Murai room $70.78 \%$, Kasuari room $48.07 \%$, Camar room $80.39 \%$, Nuri room $16.89 \%$, Merak room $5.21 \%$, Cendrawasih room $19.18 \%$, Kenari room $61.89 \%$ and Merpati room $90 \%$.

Merpati Room is an inpatient room which has the highest BOR achievement, reaching $90 \%$. The achievement of the BOR was the highest among the rooms in the Idaman Banjarbaru Hospital. This shows the high utilization rate of the bed. The high achievements of the BOR indicate that there has been an increase in the use of Inpatient Installation services in the Merpati room at Idaman Banjarbaru Hospital (IRNA Recapitulation, 2019). This condition also shows that the work activities of health workers in the room have also increased. Increased work activity can be a cause of work fatigue in nurses (Maharja, 2015). The number of beds available in the Merpati Room is 30 beds, and there are 3 officers per shift with the staff ratio, and the number of beds is $1: 10$. So it can be said one nurse in the room to handle ten beds (recapitulation IRNA, 2019). Then the amount is not following the Decree of Minister of Health No. 262 of 1979 concerning the bed- nurse ratio for type C hospitals is 2: 3 (Ministry of Health Republic of Indonesia, 1979). The number of patients more in line with weather changes and disease epidemiology, it will further increase the workload of nurses, causing work fatigue that affects work performance (Pongantung, 2018).

Fatigue can be caused by several factors including rotation work shifts, individual factors (health or disease, sex, age, education, workload, years of work and nutritional status) (Pramitasari, 2016). Several factors are suspected to be related to fatigue of nurse apes in the Inpatient of Idaman Hospital Banjarbaru, including age, sex, work shifts, years of service, marital status and nutritional status.

\section{RESEARCH METHOD}

This type of research is analytic observational research with the cross-sectional approach. In this observational study, researchers 
do not do or do not give treatment to research subjects, but the subjects themselves "choose" to do it. While the cross-sectional approach is a study that studies the correlation between risk factors, utilizing approach, observation or data collection on age, gender, work shifts, years of service, marital status and nutritional status with nurses working fatigue in the inpatient room at Idaman Hospital Banjarbaru at the same time. The research is using pieces of stuffing and Program Kosinski's Time Reaction Software as a tool for data collection. The population in this study were all nurses in the inpatient room of Idaman Banjarbaru Hospital, totalling 132 people. The sampling technique used in this study uses probability sampling with proportional random sampling.

\section{FINDINGS}

Table 1. Univariate Analysis of Research Variables

\begin{tabular}{llcc}
\hline Variable & Category & Freq & \% \\
\hline Work fatigue & Not tired & 14 & 25 \\
\hline \multirow{2}{*}{ Age } & Tired & 42 & 75 \\
\hline & $\begin{array}{l}\text { Early } \\
\text { adulthood }\end{array}$ & 35 & 62.5 \\
\hline Gender & Mid adult & 21 & 37.5 \\
\hline & Female & 31 & 55.4 \\
\hline Shift work & Male & 25 & 44.6 \\
\hline & Morning & 16 & 28.57 \\
\hline Protein Consumption Pattern & Afternoon & 20 & 35.71 \\
\hline Years of service & Night & 20 & 35.71 \\
\hline SEZ & No risk & 28 & 50 \\
\hline Marital status & Risky & 28 & 50 \\
\hline & Not Married & 15 & 26.79 \\
\hline Nutritional status & Married & 41 & 73.21 \\
\hline & Less & 12 & 21.43 \\
\hline & Normal & 41 & 73.21 \\
\hline & More & 3 & 5.36 \\
\hline
\end{tabular}

Based on the table above, it is known that the majority (75\%) of nurses in the inpatient room at Idaman Hospital Banjarbaru, who were respondents of the study experienced work fatigue. From these results, it can be seen that the majority of respondents did experience fatigue when carrying out their work as nurses. Fatigue usually shows the different conditions of each individual, but all aim to lose efficiency and decrease work capacity and endurance (Siregar, 2019).

Based on the above table, it is known that the majority $(62.5 \%)$ of nurses in the inpatient room at Idaman Hospital Banjarbaru, who was the study respondents were nurses with early adulthood. The results of this study indicate that the majority of nurses in the inpatient unit of regional hospital aged between 20-30 years. Age is related to maturity. Maturity is technical in carrying out tasks as well as psychological maturity. A person's age increases so the level of technical and psychological maturity and shows the maturity of the soul at work. However, the condition of nurses with ages between 20-30 years makes nurses less able to balance work with the psychological, environmental situation (Siregar, 2019).

Based on the above table, it is known that the majority (55.36\%) of nurses in the inpatient room at Idaman Hospital Banjarbaru, who were the respondents of the study were women. In this modern era, equal rights of women and men are the same. Women are entitled to a good socioeconomic position and how women can develop and progress over time without losing their identity, as well as men (Kondi, 2019). The condition of nurses is predominantly female, and many are married if entering work shifts, especially night shifts with long periods making nurses likely to become tired (Siregar, 2019).

Based on the above table, it is known that the nurses in the inpatient unit Idaman Hospital Banjarbaru study who were undergoing early morning work shifts of $28.57 \%$, who had as much as $35.71 \%$ afternoon shift and night shift workers who undergo as much as $35.71 \%$. Every person has different body time settings known as the circadian rhythm, in the preparation or regulation of work shifts it is necessary to pay attention to the biological time or clock that is appropriate for our body (Siregar, 2019).

Based on the above table, it is known that $50 \%$ of nurses in the inpatient room at Idaman Hospital Banjarbaru who were respondents of the study had a risky working period of $\geq 5$ years. The working period is closely related to physical abilities; the longer a person works, the more their physical abilities decrease. Physical ability will gradually decrease due to fatigue from work and can be aggravated when doing physical activities can vary in work. Indirectly, the work period will cause contraction of the strengthening muscles and abdominal buffer continuously for a long time. In all complaints that were felt by workers with a work period of less than 1 year, they experienced the most complaints. Then the complaint is reduced in the workforce after working for 1-5 years. However, complaints will increase in the workforce after working for more than 5 years (Tarwaka, 2014).

Based on the above table, it is known that the majority $(73.21 \%)$ of nurses in the inpatient room at Idaman Hospital Banjarbaru, who were respondents in the study were married. Those who are already married may have the risk of experiencing burnout if the marriage is not harmonious or has a partner who cannot provide social encouragement, including support for work.

Based on the above table, it is known that the majority $(73.21 \%)$ of nurses in the inpatient room at Idaman Hospital Banjarbaru, who was the study respondents had normal nutritional status. Workers need the energy to be able to work. Fulfilment of nutrition to be able to work must not only be met quantitatively, but also in terms of the nutritional quality of the food consumed. Adequate and balanced eating during the day and before going to sleep significantly affects alertness and quality of sleep. Maintaining health and weight condition not only increases stamina but can also reduce the possibility of sleep disturbance. Proper nutrition and good physical condition have a significant influence on the effects of fatigue (Maghfiroh, 2015).

Table 2. Bivariate Analysis with Chi-Square and Fisher Exact

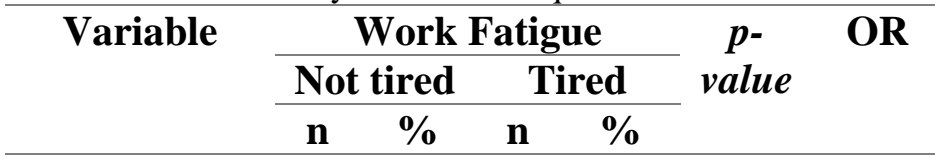

Age 
experience much less work fatigue than those who have a risky tenure. Although with a long work period a nurse gets a lot of work experience, but the monotonous and human service pattern of nurses' work causes physical, emotional and psychological fatigue that leads to heavy work fatigue (Sari, 2015).

Based on the results of bivariate statistics, it is concluded that there is an influence of marital status on nurses working fatigue in the inpatient room at Idaman Hospital Banjarbaru. The influence of marital status on work fatigue is caused statistically due to work fatigue due to more work fatigue in nurses with married status whereas nurses with unmarried status who experience work fatigue are far less than those who are married. Marriage causes increased responsibilities which can make work more valuable and important. So someone who is married will experience work fatigue due to work and when he gets home, he must take care of family needs which time should be used for rest (Huriahni, 2017).

Based on the results of the bivariate statistics, it was concluded that there was no effect of nutritional status on nurses working fatigue in the inpatient room at Idaman Hospital Banjarbaru. This can be caused by work fatigue, especially heavy work fatigue both experienced by nurses who have more or normal nutritional status. Lack of nutritional value of food consumed by daily workers will bring bad effects on the body, such as the body's defence against disease decreases, physical ability decreases, body weight decreases, lack of enthusiasm and lack of motivation, reacts slowly and apathy. In such circumstances, it cannot be expected to achieve efficiency and optimal work productivity. In carrying out the work process, a worker needs adequate sleep and balanced nutrition to be able to maintain work capacity. If the work capacity of a worker is well preserved due to enough sleep and sufficient nutrition, work fatigue that occurs can be minimized (Maghfiroh, 2015).

Based on the results of multivariate statistics, it was concluded that the variable of tenure and marital status influenced work fatigue. The longer a person works, the experience also increases, but the monotony of work so that symptoms arise from work fatigue. Nurses with tenure who are not at risk can experience work fatigue because they are able to adapt to work and their environment so that symptoms of work fatigue arise (Suma'mur, 2014).

Based on the results of the study, nurses who have been married 13,927 times will be more likely to experience work fatigue. Nurses who are married are more likely to experience depersonalization. This happens because the situation is also influenced by external factors, namely in the family environment, such as conflicts within the family, and the conflict is brought to the workplace so that it affects others. When individuals experience depersonalization, it will be difficult for them to be interested again in the activities they have been engaged in. They will start to get bored, uncomfortable and cynical about what is around them to make work fatigue possible (Awalia, 2013).

\section{CONCLUSION}

1. There was no significant influence between age, gender, work shift, and nutritional status with work fatigue in nurses in the inpatient unit at Idaman Hospital Banjarbaru.
2. There is a significant influence between a work period and marital status with work fatigue in nurses in the inpatient unit at Idaman Hospital Banjarbaru.

3. Marital status is the most dominant factor influencing work fatigue in nurses in the inpatient unit at Idaman Hospital Banjarbaru

\section{REFERENCES}

Bijani M, 2016. Factors Influencing Poor Nursing Documentation from The Perspective of Nursing Staff. International Journal of Medical Research \& Health Sciences, Vol . 5, No.11, 2016; 717-718

Head of Inpatient Installation. IRNA Civil Service Report 2019 . Banjarbaru: RSD Idaman Banjarbaru Management, 2019

Idaman Hospital Banjarbaru. Profile of Idaman Hospital in 2019 . Banjarbaru: RSD Idaman Banjarbaru Management, 2019

Kondi AE, 2019. Factors Related to Work Fatigue in Nurses at the Early Bross Bekasi Hospital. Jurnal Persada Husada Indonesia, Vol. 6, No. 20, 2019.

Maghfiroh S, 2015. Relationship between Stress Tolerance, Work Shift and Nutritional Status with Fatigue in IGD and ICU Nurses (Study at Sultan Agung Hospital in Semarang ). Indonesian Public Health Journal, Vol . 10, No. 2, 2015.

Maharja, 2015. Analysis of the Level of Work Fatigue Based on the Physical Workload of Nurses in the Inpatient Installation of Surabaya Haji Hospital. The Indonesian Journal of Occupational Safety and Health, Vol. 4, No. 1: 93-102.

Ministry of Health Republic of Indonesia, 1979. Decree of the Minister of Health of the Republic of Indonesia No. 262 of 1979 concerning Hospital Personnel. Jakarta: State Secretariat

Mulfiyanti D, 2019. The Relationship between Work Stress and Workload with Work Fatigue in Nurses at General Hospital in Class B Bone Bone Regency in 2018. Journal of MKMI, Vol. 4 No.1, December 2019.

Pongantung M, 2018. The Relationship Between Workload and Work Stress with Work Fatigue in Gmim Kalooran Amurang Hospital Nurse. KESMAS Journal, Vol. 7 No. 5, 2018.

Pramitasari, 2016. The Influence of Working Periods and Work Shifts on Work Fatigue in Inpatients at Surakarta's Pku Muhammadiyah Hospital. Scientific Publications. Surakarta: Muhammadiyah University Surakarta, 2016.

Ramdan IM, 2016. Analysis of Factors Related to Burnout in Mental Health Nurses. Padjadjaran Nursing Journal, 2016.

Sari NLPDY, 2015. Relationship of Workload, Demographic Factors, Locus of Control and Self-Esteem Against Burnout Syndrome in Nursing Nurse Ird Rsup Sanglah. Coping Nurse Journal Vol. 3, No . 2, May-August 2015.

Siregar T, 2019. Relationship between Work Shift and Fatigue Level of Nurses in the Emergency Room at Budhi Asih Hospital, East Jakarta. Jurnal Persada Husada Indonesia, Vol. 6, No. 22, 2019.

Suma'mur PK, 2014. 2014. Corporate Hygiene and Occupational Health. Jakarta: Sagung Seto

Tarwaka, 2014. Ergonomics for Occupational Health and Productivity. Surakarta: UNIBA Press

\section{AUTHORS}

First Author - Yunita Suwarni, Master of Public Health, Faculty of Medicine, Lambung Mangkurat University, Indonesia.

Second Author - Izaak Zoelkarnaen Akbar, dr. HM Ansari Saleh Regional General Hospital, South Kalimantan, Indonesia.

Third Author - Eko Suhartono, Department of Biochemistry, Faculty of Medicine, Lambung Mangkurat University, Indonesia. Fourth Author - Husaini, Master of Public Health, Faculty of Medicine, Lambung Mangkurat University, Indonesia.

Fifth Author - Fauzie Rahman, Public Health Study Program, Faculty of Medicine, Lambung Mangkurat University, Indonesia. Correspondence Author - Khairunnisa, Master of Public Health, Faculty of Medicine, Lambung Mangkurat University, Indonesia, email: adenaliliana@gmail.com 
International Journal of Scientific and Research Publications, Volume 10, Issue 8, August 2020 